\section{Fenomenologia da televiolência}

\section{RESUMO}

Neste artigo 0 autor analisa, dentro de uma abordagem antropo-sociológica e fenomenológica, a representação da violência na mídia televisual brasileira, cujas técnicas de visualização apresentam formatos intimistas e passionais ou mesmo preconceituosos e agressivos. $\mathrm{O}$ objeto se torna assim seu próprio método de encenação.

\section{ABSTRACT}

This article analyses the representation of violence on Brazilian television, whose visualization techniques appeal to intimate and passionate formats, if not prejudiced and agressive. This way, the object of analysis becomes the very method of its presentation.

\section{PALAVRAS-CHAVE (KEY WORDS)}

- Fenomenologia (Phenomenology)

- Televiolência (Tv violence)

- Informação/Entretenimento (Information/Entertainment)

\section{Philippe Joron*}

Sorbonne - Paris V / França
A TELEVIOLÊNCIA, mais precisamente a telerrealidade da violência, nas suas modalidades brasileiras, é um fenômeno relativamente recente em termos de comunicação de massa. Mesmo se nos tempos remotos sempre existiram formas de divulgação da violência (relatos escritos ou orais, gravuras, circos ou teatros itinerantes, execuções publicas, etc.), a televisão propiciou por sua vez o acesso de um largo público aos acontecimentos contundentes da vida cotidiana, coincidindo com uma certa liberdade de expressão jornalística que tentava praticar sua relativa autonomia em relação aos poderes do Estado ou de outros grupos de influência. Assim, o Aqui Agora foi o primeiro programa televisual do gênero, de audiência nacional, surgindo no início da década de noventa do século XX. De lá para cá se implantaram na paisagem audiovisual brasileira, de um modo que à primeira vista poderia ser avaliado como sendo sintomático, várias formas de jornais policiais, tanto como programas de entretenimento ou até de informação que se utilizaram do registro da violência mostrada.

\section{Exumação da violência}

Essa inflação televisual da violência, o uso exponencial da violência como objeto de arrecadação de audiência é a expressão visível de uma certa concepção normativa para qual se trataria de um fato patológico e não constitutivo das sociedades ou das construções sociais e culturais. O sociólogo Patrick Baudry apresenta as evidências dessa problematização nos seguintes termos: “Não é a violência que deve preocupar. Mas a fabricação sistemática da violência como problema, como si este problema podia ou devia reunir-nós."1 Á partir dessas constatações, acionadas também pelo interesse do público por esse ramo jornalístico, me proponho expor aqui alguns resultados de 
análise relativos ao tratamento midiático da violência brasileira ${ }^{2}$. Segundo Muniz Sodré, trata-se de uma violência representada, "discursivamente modalizada e manejada tanto pelo jornalismo que tende a visibilizar publicamente a agressão recorrente na vida cotidiana quanto pela indústria do entretenimento, especialmente em filmes e programas de televisão, com a finalidade de conquistar maior audiência ${ }^{3}$." Veremos que não existe uma forma de televiolência propriamente dita, mas diversas modulações entre as quais o tipo da violência representada diverge do tipo da violência mostrada. Nessa distinção, fica claro que o papel desempenhado pela mídia televisual se torna fundamental, sabendo sua íntima vinculação à presença soberana do público.

Televiolência e telerrealidade da violência não têm o mesmo significado por se expressarem de formas distintas em campos de atuação hierarquizados. A primeira se apresenta como forma geral da violência midiatizada ou comunicada, enquanto a segunda se define como um tipo específico que pretende se adequar "à vida como ela é". Ela partilha assim o espaço televisual da violência com um outro tipo especifico, preenchido pelas obras ficcionais ou simulativas, que chamarei aqui de telerreconstituição da violência. Essas definições provisórias são necessárias, mesmo se elas se encontram distorcidas pela complexidade do fenômeno estudado, na medida em que permanecem dificuldades tipológicas ao decorrer da análise para classificar tal ou tal programa dentro dos paradigmas realístico ou reconstrutivo dessa violência genérica. Vale a pena ressaltar também aqui a existência de uma linha de atrito característica das estratégias televisuais brasileiras entre a ideologia da violência telerreal e a da teleficção. De um lado, temos a filosofia do jornalismo policial produzido pelas redes de televisão da SBT, Record, Rede TV e Bandeirante, que encara a violência como uma sorte de hiper-realidade brasileira. Do outro lado, a indústria ficcional da Rede Globo, emissora que não investiu no ramo do jornalismo policial, à não ser num único programa de reconstituição e de investigação jornalística chamado Linha direta. A verdade da vida real nas suas extremidades mais trágicas é assim confrontada à falsidade da vida imaginada: "Os freaks nossos de cada dia ${ }^{4 "}$ contra os heróis estereotipados do nosso imaginário eterno. Mas verdade e falsidade, assim como realidade e imaginário não tem territórios delimitados de uma vez por todas, as fronteiras podendo flutuar, se cruzar e até se apagar em função das circunstâncias. Como aponta uma análise aguda de Muniz Sodré sobre o Horror Show e o catastrofismo, a violência midiatizada revela-se "um excelente operador semiótico para hibridações ficcionais entre realidade e imaginário ${ }^{5}$."

A programação televisual do jornalismo policial brasileiro distribui-se em dois horários de difusão, de segunda à sextafeira. No primeiro, entre meio dia e meio e uma hora e meia da tarde, são apresentados por emissoras locais acontecimentos referentes à violência ocorrendo em cada Estado e à atuação policial para combatê-la. No caso de Pernambuco, três programas do gênero destacam-se: Blitz na Cidade, da TV Jornal/SBT (canal 2); Cardinot na Tribuna, da Tribuna/Record (canal 4); Pernambuco Urgente, da TV Guararapes/Band (canal 9).

O segundo horário, entre dezoito e dezenove horas e trinta, é reservado aos jornalismos policiais de audiência nacional. Assim como anteriormente, três programas oferecem leituras peculiares da violência disseminada no país, tendo São Paulo e Rio de Janeiro como pólos de atenção privilegiados: Cidade Alerta, da Record (canal 4); Repórter Cidadão, da Rede TV (canal 6); Brasil Urgente, da Band (canal 9). Deste modo o telespectador pernambucano tem ao seu alcance, ao vivo, seis programas de jornalismo policial stricto sensu, aos quais adicionam-se, logo antes ou depois dos referidos horários, os jornais de informação convencionais que repassam algumas dessas matérias focalizadas no tema da violência, contudo de um modo mais suave, sem 
a mesma tensão dramática ou cômica que caracteriza esses mostruários comunicacionais da violência urbana, suburbana e rural.

\section{Subsídios fenomenológicos}

Por se tratar de uma forma especifica de comunicação televisual envolvendo "agentes" de produção, divulgação e recepção de fatos que chamam a atenção, a televiolência abre um espaço de reflexão significativo sobre o que eu destacarei aqui como sendo um aparato fenomenológico de conhecimento comum. Com efeito, o problema da divulgação da violência nos meios de comunicação contemporâneos limitados neste estudo ao registro televisual, envolve algumas das dimensões próprias ao que se poderiam chamar de "hermenêutica do vivido", ou seja, a interpretação da carga simbólica contida em toda experiência vivida, como é particularmente o caso da violência enquanto experiência extrema. É preciso então distinguir por um lado o tratamento fenomenológico que poderia ser dado ao estudo da televiolência em termos de metodologia aplicada em ciências humanas de modo geral e mais especificamente em ciências da comunicação e por outro lado a dimensão fenomenológica que poderia-se encontrar no tratamento telejornalístico da violência no Brasil. Eu pretendo delinear apenas algumas pistas de reflexão relacionadas a essa segunda vertente, ou seja, as principais características da "fenomenologia jornalística" enquanto objeto de pesquisa privilegiada aqui.

Nas suas fundamentações filosóficas, a fenomenologia de Edmund Husserl (18591938) se constituiu a princípio em função de um questionamento relacionado à natureza da cientificidade: como uma verdade pode ser apreendida por uma subjetividade? Um dos seus principais objetivos era mostrar e de uma certa forma resgatar o papel fundamental da subjetividade dentro de toda intenção científica. Outros cientistas da época, na tradição alemã da filosofia social, complementaram essa linha de pensamento insistindo sobre a especificidade intrinsecamente humana dos "objetos" próprios às ciências humanas e, portanto sobre as suas adequações com o pensamento daquele que tenta desvendar a complexidade dos fenômenos sociais: os trabalhos de alto bordo, originais e precursores de pensadores como Wilhelm Dilthey, Max Weber ou ainda Georg Simmel em torno dessas questões permitiram novas abordagens da matéria prima social dentro do paradigma compreensivo da sociologia.

A fenomenologia poderia-se definir então tanto como um sistema de pensamento (fenomenologia pura) que se esforçaria em buscar o último princípio de toda realidade, mas também enquanto método que tentaria apreender as essências, a natureza dos fatos empíricos por meio da descrição e não apenas dos procedimentos explicativos.

Sem levar em consideração essas preocupações epistemológicas que ultrapassam o quadro restrito da perspectiva antroposociológica apresentada no momento, é preciso, contudo relembrar que a fenomenologia social foi introduzida na sociologia francesa por Raymond Aron em 1935 com a publicação do seu estudo sobre a sociologia alemã ${ }^{6}$ e incorporada no projeto intelectual e até político de vários estudiosos da época, em áreas diversas de conhecimento. Assim Roger Caillois, Jules Monnerot e Gaston Bachelard, no contexto dos acontecimentos trágicos configurados pelo nazismo, adotaram e adaptaram essa postura compreensiva afim de "apreender de dentro o fenômeno social, na sua essência pura, na sua totalidade e seu dinamismo imediato ${ }^{7}$."

Essa nova amplitude dada à sociologia será em seguida formulada por Jules Monnerot em Les faits sociaux ne sont pas des choses na tentativa de discutir os princípios fundadores das Regras do Método Sociológico emitidos e espalhados de forma hegemônica por Emile Durkheim ${ }^{8}$ e seus colaboradores nos meios acadêmicos: assumindo um posicionamento contrário ao dos argumentos científicos contidos no preceito durkhei- 
miano em busca de legitimidade e validade para a ciência sociológica, ciência holística por excelência, Jules Monnerot considera que os fatos sociais não podem ser tratados como se fossem coisas na medida em que os indivíduos, historicamente datados e situados, ao mesmo tempo determinados pelas estruturas sociais e produtores de vontades e liberdades das mais diversas, não reagem de modo sistemático no sentido esperado quando são estimulados por um ou vários fatores culturais ou naturais ${ }^{9}$. De um ponto de vista metodológico, a resposta de Monnerot desmancha a pretensão durkheimiana em relação à suposta objetividade do sociólogo diante dos fatos que ele pretende circunscrever e explicar. Esse modo de pensar e de praticar as margens da sociologia, na periferia da ciência durkheimiana, já tinha encontrado terrenos prediletos nos fenômenos estudados (guerra, festa, sagrado, vida cotidiana, etc.) pelos integrantes do Colégio de Sociologia sagrada entre 1937 e 1939, entre os quais se destacava Georges Bataille e sua perspectiva transgressiva ${ }^{10}$.

Fica evidente que a fenomenologia social, fundamentada por questões filosóficas (a apreensão da verdade e da realidade), sustentada por aparelhagens epistemológicas (a arquitetônica da racionalidade dentro do pensamento científico), se expressa de diversas maneiras sem constituir, portanto um modelo único de reconstrução dos fenômenos sociais ${ }^{11}$. Mas é possível delimitar alguns traços característicos comuns que interessam o desvendamento, mesmo parcial, da televiolência enquanto fenômeno comunicológico contemporâneo. Assim, toda perspectiva fenomenológica desenvolve considerações axiológicas, gnoseológicas e "empaticológicas". A dimensão axiológica da fenomenologia configura uma abordagem crítica da noção de valor propriamente dito, considerando a ideologia do racionalismo moderno como o epicentro de um conjunto de valores morais que submetem o ideal de realização da humanidade aos progressos da Ciência, que por sua vez determina os objetos, os métodos e as áreas de pesquisa a serem privilegiados. Por outro lado, a dimensão gnoseológica da ótica fenomenológica explora as várias facetas do conhecimento que, sem exclusivas, participam da produção do social ${ }^{12}$ em termos de relações, obras, culturas, utopias, história, destino, etc. Enfim, a terceira dimensão que eu defini como sendo "empatológica", se interessa à ênfase dada aos procedimentos de identificação, de alteração e de substituição, geralmente parciais e momentâneos, contidos no ato de compreensão (abraçar) das experiências dos outros. Essas dimensões estão relacionadas entre elas e constituem três das principais portas de entrada da fenomenologia social.

\section{A violência como ela é}

Há uma linha de conexão entre essas três dimensões que pode ser identificada pela noção de distanciamento (dentro do seu grau de amplitude) que envolve acontecimentos, indivíduos que os induzem (agentes produtores), aqueles que os divulgam num certo sentido (agentes emissores) e aqueles que os vivenciam por meio mediático (agentes receptores).

As posições respectivas do produtor, do emissor e do receptor diante do acontecimento, nos programas policiais e em alguns programas de entretenimento que exploram as vicissitudes da natureza humana, aparecem como em busca de um distanciamento minimalístico. De forma paradoxal, mas não necessariamente ilógica, a quase ausência de distanciamento (espacial, temporal e até reflexivo) diante da violência exibida, coexiste com a postura paternalista (aquela que dá carinho e também castiga) do apresentador. Essa base contraditorial serviria de apoio metodológico ao papel educativo desenvolvido pela mídia popular brasileira (principalmente a televisão aberta, já que o acesso à televisão a cabo só se faz por assinatura) que apresenta formatos e conteúdos enfáticos, para não dizer caricaturais. A falta de distanciamento (o mergulho do 
jornalista, do comentarista e do telespectador dentro do acontecimento ao vivo) está também proporcionada à redundância das imagens e dos comentários. Ao mostrar a violência como ela é ${ }^{13}$, de forma repetitiva e focada, esses programas de jornalismo policial reivindicam uma verdadeira missão educativa: alertar as instâncias políticas, jurídicas e policiais, colocá-las em frente às suas responsabilidades, e mostrar, sobretudo o que é cidadania, repleta de direitos, mas também de deveres.

Por outro lado, essa missão educativa, quase evangélica em certos aspectos, trata de praticar uma informação ativa ou operacional em direção à população, tomando o rumo dos acontecimentos, catando o "lixo social", incentivado o uso do disque denuncia e indicando à força as direções do certo e do errado: um verdadeiro tratamento de choque para expulsar o Mal que estaria corroendo o tecido social. Obviamente, as reivindicações repletas de apelo a Deus ou a Jésus Cristo não constituem uma originalidade em si nesses pro gamas em relação a outros ou à população brasileira de um modo geral. A sustentação religiosa, com traços reformados, deve ser procurada em outro campo: na presença, na fala e nos gestos do apresentador que lembra muito à atuação de um pastor praticando um exorcismo em frente à platéia de fiéis, tanto quanto na dimensão sacrificial do processo ostentador da violência, partilhando simbolicamente com o público a carne e o sangue das vítimas.

Estamos aí diante de uma mensagem convencional, conservadora, que justifica sua audiência pela urgência de uma remoralização da sociedade, supostamente angustiada pelo liberalismo dos seus costumes e a alta velocidade das suas transformações: uma mensagem radiográfica e até tomográfica que disseca tanto a violência invisível quanto à violência visível, isto é por um lado a "violência institucionalizada" ou "estado de violência" e por outro lado a "violência anômica" ou "ruptura da ordem jurídico-social", conforme a distinção utili- zada por Muniz Sodré e outros especialistas desta área de conhecimento ${ }^{14}$.

Contudo, é difícil senão impossível medir a eficácia dessa visualização trash e todas as interpretações ficam abertas à análise. Não é o objeto deste ensaio abordar de modo explícito a telerrealidade da violência dentro de uma discussão sobre a pertinência ou a validade supostamente comprovada das teorias da comunicação em torno dos efeitos ou da recepção ${ }^{15}$.

Todavia, o teor educativo da televisão brasileira deixa pensar sem a menor dúvida que as produções, quaisquer que sejam, funcionam a partir do postulado da unilateralidade e da univocidade mesmo quando se promove a roupagem da interatividade e da liberdade de pensamento: as informações, ou melhor as mensagens e seus significados teriam um efeito sobre o receptor, um efeito pré-concebido e portanto desejado que despeja a idéia de pluralidade e de acaso.

A mídia televisual difunde assim uma concepção da educação que muitos qualificam como sendo paternalista e infantilizante, perceptível até nas telenovelas que dão lições de vida ao povo (integrando, por exemplo, no roteiro a atualidade de ou tal programa social, ou a importância de se votar com consciência no momento das eleições, etc.), visível ainda na sopa de notícias extraordinárias do Fantástico (programado no domingo à noite) da Rede Globo que utiliza como grife a voz além-temporal e cavernosa do jornalista Cid Moreira a fim de indicar para o público brasileiro quais serão, por exemplo, as modificações evolutivas sofridas pelos animais e vegetais no decorrer dos próximos cinco milhões de $\operatorname{anos}^{16}$. Se por um lado considera-se que a recepção de uma mensagem esta conforme ao que se esperava, acredita-se por outro lado que os impactos sobre os receptores desencadeiam efeitos contrários aos planejados. Existe por exemplo um grupo de incentivo à cidadania chamado Antivacina que assume posições extremamente críticas em relação a essa visibilidade televisual da violência. Segundo os seus integran- 
tes e simpatizantes, as doses de violência inoculadas pela mídia, mesmo por serem contraídas em poucas quantidades no dia a dia, imunizariam o povo contra este veneno social, o deixando mais apático do que era: a banalização da violência esmagaria a conscientização ${ }^{17}$.

Mas é preciso diferenciar o conteúdo e a plasticidade das imagens mostradas das formas de apresentação ou mesmo de encenação. Assim, não é tanto a imagem propriamente dita que traz problema, mas, sobretudo a maneira de colocá-la no prisma televisual, ou seja, o tratamento midiático da violência que por si só contém falhas e excessos de todos os tipos: os gestos, a movimentação, a fala do apresentador podem ser interpretados como sendo agressivos e até preconceituosos. Essa análise vale também para a formatarem das imagens e a construção do roteiro, sob a responsabilidade da produção do programa, que interpretam o cotidiano dentro de um quadro sensacionalista e catastrofista ${ }^{18}$. É uma violência que poderíamos definir como etérea ou estratosférica já que esta no ar, no sentido próprio como também no figurado.

Mas nem é por isso que se torna necessariamente soporífica, ao contrário do que poderia-se pensar a respeito de alguns programas ditos de informação que mostram um Brasil liso, sem asperidade existencial, e um mundo ornamental, percorrido ou viajado por procuração. $\mathrm{O}$ jornalismo policial tem pelo menos o mérito de espelhar um cotidiano feito de grandes e pequenos acontecimentos, o dia-a-dia dos indivíduos e das comunidades mergulhando num sentimento de insegurança que tem força de lei. É, portanto um espelhamento forçado por um certo contexto social, político e cultural (o chamado estado de violência) que por sua vez concentra uma parte da população nos condomínios fechados e nos Shopping Centers, tranca outra parte atrás das grades e coloca a grande maioria frente às suas necessidades básicas.

Trata-se aí de uma realidade desviada, perturbada pelo olhar inquisitorial de uma certa filosofia midiática, ou simplesmente reelaborada de modo imprescindível pela cultura jornalística, cuja busca de objetividade esta enraizada nos pilares emocionais da subjetividade? No entanto, sabe-se que o potencial de deformação da imagem atribuído ao próprio espelho se deve também ao olho seletivo e criativo de quem se reflete. Não se ponha em dúvida o processo de transformação da própria realidade quando é colocada em perspectiva, a partir do momento em que ela é selecionada, recortada, produzida, argumentada pela função jornalística segundo critérios profissionais, culturais, pessoais ${ }^{19}$.

Além disso, esse mesmo processo de transformação é também presente no ato de recepção, em função da história, do habitus, do contexto, das preocupações de cada um dos telespectadores. Mas no cruzamento dessa dupla produção de sentidos, a análise da problematização da violência pela mídia enquanto fenômeno contemporâneo não deve descartar a distinção tipológica entre violência mostrada e violência representada. Para atingi-la uma outra diferenciação deve ser feita entre violência noticiada e violência reconstituída: a primeira tal como ela se apresenta nos programas de jornalismo policial diário acima citados, que tratam de mostrar, comentar e apurar os crimes ou atos delituosos que acabaram de acontecer; a segunda tal como se encontra no programa Linha direita da Rede Globo e em algumas matérias de Repórter Cidadão da Rede TV que utilizam atores para simular o decorrer dos fatos, après coup, na tentativa de reconstituir o crime e o seu contexto de atuação.

Do mesmo modo, é preciso diferenciar a violência em ato da violência imaginada, ou seja: de um lado uma apresentação da violência dentro da sua execução seqüencial, como por exemplo, uma perseguição policial ao vivo ou ainda um assassinato gravado por um cinegrafista amador; do outro lado uma apresentação da violência dentro das suas conseqüências ou das suas evidências no lugar de ocorrência, como um 
corpo baleado ou um carro arrombado. Se a violência é plural nas suas atuações, seus modos operatórios, suas experiências e sua produção de dor, ela recebe o mesmo tratamento da parte da mídia que modela diversas formas de apresentação, isto é várias perspectivas de encontro com o público. No fim, violência mostrada e violência representada se definem uma em função da outra no nível da intenção, do postulado jornalístico que está por traz, e não apenas no plano das técnicas de visualização que estão a serviço. Mostrar significa antes de tudo apelar às emoções básicas do destinatário, projetar no olhar do outro uma matéria-prima, bruta. Representar é deixar ver num certo sentido, propor uma construção, uma linha de pensamento ou de sentimento determinada.

\section{O riso da violência}

Como já foi sugerido, a informação relativa ao estado e aos atos de violência é divulgada ora de maneira dramática ora de forma cômica, adequando assim a força das imagens e das testemunhas à impressão de dominar pelo verbo e pelo gesto o lado escuro da existência, tanto nos seus laços culturais como naturais, essa "parte maldita" 20 circunscrita pelo teor moral das consciências individuais e pela coerção do grupo de referência sobre a modelização dessas mesmas consciências. Por um lado, a dramatologia da televiolência é particularmente notável através da postura presunçosa, da voz altissonante, do gesto contundente daquele que fica encarregado de apresentar e, sobretudo de comentar as imagens, recebendo ainda o apoio de um fundo sonoro estrondoso (retumbante) esquartejado entre músicas de suspense e sirenas de viatura policial. Neste caso, o profissional assume simultaneamente tanto o papel de tabelião público, registrando os atos de violência no cartório jornalístico, como aquele do juiz que sanciona no tribunal televisual, além das suas obrigações corporativas em alertar, denunciar, informar. Por outro lado, a televiolência brasileira se utiliza também do registro da comicidade e da brincadeira em alguns desses programas de jornalismo policial, como no caso de Blitz na Cidade, Cardinot na Tribuna e em certos aspectos Repórter Cidadão. Acredita-se que a informação, por ser bem orientada e supostamente recepcionada, precisa vestir a fantasia do entretenimento, do divertimento. Estratégia político-econômica ou necessidade cultural?

Trata-se talvez de um imperativo existencial, na medida em que o distraimento, como o imaginário, é um empurrão dado à morte, um desvio da angústia mórbida. Por explorar o vazio desta angústia propriamente dita, o riso possibilita essa eufemização que é também uma maneira de afrontar o destino ${ }^{21}$. No seu estudo sobre o êxtase e as experiências extremas da comunicação, Georges Bataille aponta o seguinte paradoxo: "O riso em comum supõe a ausência de uma verdadeira angústia, e contudo ele não tem outra fonte do que a angústia ${ }^{22}$." O heterólogo social ${ }^{23}$ faz esta constatação para mostrar que o riso, quando é partilhado em torno de um objeto de gozação, propicia entre as pessoas uma corrente de comunicação intensa que quebra o isolamento de cada uma. De fato, os comunicólogos e os profissionais da mídia conhecem a importância do prazer da gozação como fator de ligação comunicacional que, por estar somado ao impacto das imagens de violência, seria um elemento propulsor de audiência e consequentemente, de retorno financeiro.

Assim, dois dos três programas pernambucanos de jornalismo policial que partilham a programação do meio dia fizeram essa opção e investiram na brincadeira enquanto reforço ou vetor de comunicação. Blitz na Cidade, apresentado por Jota Ferreira, beneficia de uma platéia que se posiciona também como elenco, já que alguns dos seus integrantes terão a oportunidade de contar com o apoio do jornalista para tentar resolver problemas pessoais, como por exemplo, a busca de familiares desaparecidos. A participação do público é também solicitada, em termos de gozação e 
de reprovação, para cada matéria relatando crimes de todos os tipos que aconteceram na região metropolitana de Recife ou no interior do Estado.

Como é comum afirmar neste programa, a cada dia é um "festival de mortes", aparente dicotomia que reforça mais uma vez o entrelaçamento entre o gozo, a gozação e a violência. De vez em quando o comentarista segura na mão um chicote $^{24}$ usado para bater na mesa ou num palhaço (cujo apelido é "Namídia") que não para de percorrer o palco de um lado para o outro e que tem por principal função dar descarga num vaso sanitário quando o Jota Ferreira decide sancionar o autor do crime ocorrido (roubo, latrocínio, estupro, "queima de arquivo", etc.), sentenciando: "Jogue na privada!" Estimula-se ainda a radicalidade da platéia, das testemunhas e dos telespectadores na expressão das suas emoções imediatas, ao exemplo do incentivo dado por uma voz "em off" que martela: "Que baixaria desgramada!" Por sua vez o apresentador do outro programa em pauta, Cardinot na Tribuna, dedica uma parte do seu horário a entrevistar casais ou parentes que brigam ao vivo, geralmente em torno de problemas de adultério ou de paternidade.

Conforme o depoimento do próprio Cardinot $^{25}$, são os protagonistas que procuram o programa (e não o contrário) na expectativa da resolução de uma situação conflituosa, ou ainda do beneficio quando for o caso de um exame de DNA gratuito. Isso sem ter necessariamente consciência da imagem negativa que vão expor frente à comunidade e aos familiares. Essas situações são objeto de gozação apesar da carga dramática das histórias contadas, bem abaixo, contudo do que se pode imaginar sobre o cotidiano destas pessoas atuando no seu direito de aparecer. Neste mesmo programa, entre duas matérias de jornalismo policial, o apresentador vende os méritos de alguns produtos comerciais, publicidade caseira que obviamente sustenta em parte a produção do programa. Um desses produtos é um sabão em pó que segundo Cardinot "lava até alma sebosa." Faz-se também o elogio a um creme contra todos os tipos de micose que o telespectador deverá passar na pele se não quiser "passar vergonha" ao expor os seus danos dérmicos. Sem querer levantar uma suspeita de qualquer ordem, pode-se pelo menos apontar uma estranha coincidência no que diz respeito o conteúdo dessas publicidades (lavar, limpar, curar, sarar, etc.) e as intenções mais ou menos higienistas do jornalismo policial que trata de mostrar, diagnosticar a sujeira ou as feridas do tecido social a fim de contribuir ao seu saneamento graças a uma melhor eficiência política, judicial e policial.

São exemplos, obviamente contextualizados, característicos do teor burlesco que pode ser encontrado no tratamento midiático da violência. Por ser normativo, esse estatuto cómico-trágico do horror mostrado, é desprezado por aqueles que se posicionam cultural e economicamente como sendo diferenciados em relação ao povo (categoria abstrata, alvo de louvores e preconceitos) e aos seus sentimentos básicos. Mas o sistema de valores em vigor, historicamente datado e situado, por mais que seja revelador de uma mentalidade sóciocultural determinada, coabita com inclinações intrinsecamente humanas (entre as quais destacam-se neste caso a violência, a curiosidade e a gozação, ao lado da piedade, da generosidade e do sentimento de culpa) cujo potencial de atuação é partilhado por todos, quaisquer que sejam a espessura e a consistência do patrimônio cultural, econômico e simbólico. A violência é uma constante variável, o riso também, tanto quanto a nossa fascinação pelo sexo e a morte. Execuções em praças públicas, lapidações, Freaks Shows, vinganças pós-guerra, humilhações fotografadas, decapitações filmadas, a lista é longa desse apelo à violência mostrada, partilhada, sintonizada, dos tempos mais remotos aos planaltos macabros da atualidade internacional.

\section{Os restos das imagens}


Afinal de contas, porque assistimos a esse tipo de programa? Falta de opções ou gosto imoderado pelo lado escuro da vida? Força agregativa do maléfico ${ }^{26}$ ? Necessidade cultural, nutrida por essa violência contextual, ambiental que surge a qualquer momento na próxima esquina? Acabei de dar elementos de reflexão que possibilitarão talvez alguns esboços de resposta. Entre eles três dos segmentos programáticos da fenomenologia jornalística, tais como foram colocados aqui numa postura compreensiva bastante caricatural e irreverente: axiologia, gnoseologia e "empatologia". Assistimos, aceitamos as imagens e os quadros dessa visualização na medida em que se utilizam técnicas, da parte dos agentes emissores, que facilitam a nossa adesão.

Assim, de um ponto de vista axiológico, a capa teatral do jornalismo policial trata de dividir o mundo em duas partes incompatíveis entre elas, cada uma com o seu próprio sistema de valores, sem que qualquer forma de relatividade pudesse ser levada em consideração: o Bem e o Mal têm papéis, lugares e protagonistas bem definidos. É neste sentido que eu falei de uma espécie de evangelização, de uma moralização da sociedade brasileira que permitiria adequar o paraíso civilizacional ao paraíso das origens, saindo assim do purgatório contemporâneo que tem valor de prova. Por outro lado, desta vez de um ponto de vista gnoseológico, essa forma de jornalismo utiliza uma linguagem comum, no sentido nobre da palavra, isto é partilhado por todos, cuja falta de complacência (notável no uso desbocado da vulgaridade) destina-se paradoxalmente a agradar à maioria. Trata-se aí de dar informações sobre os diversos perfis da violência, de vigiar numa perspectiva panótica ${ }^{27}$, de posicionar o jornalismo policial como uma forma de telealarme acessível a todos: a televiolência dá informações valiosas sobre as estratégias do crime organizado ou as técnicas de assalto, incentivam o uso do disque-denúncia, proporciona dicas sobre a maneira de evitar armadilhas, divulga as operações policiais de combate ao crime, inclusive as táticas usuais adotadas pelos próprios integrantes da corporação das quais se aproveitam também os criminosos que têm acesso às fontes de informações policiais e midiáticas (como a visualização do "cenário de guerra" por helicóptero) para contornar o trabalho da lei. Enfim, numa terceira perspectiva definida como sendo "empatológica", o jornalismo policial trabalha o potencial identificatório das imagens assim como os sentimentos de atração-repulsão que a violência mostrada aciona nos agentes receptores.

Além deste potencial, contido de fato numa imagem de qualquer natureza tanto quanto na violência de forma geral, e especialmente na imagem enquanto representação da violência, o processo de identificação do público é otimizado por um trabalho de investigação ao vivo graças ao tremor da câmera e da voz que acompanha o desenrolamento dos fatos, despertando assim o interesse da busca como si cada um participasse realmente dela.

A identificação é também solicitada de forma ativa ora pelo comentarista, que simula um diálogo com o auditório ("A vida política neste país é uma pouca vergonha, não é?"; etc.), ora por uma voz em off que exprime o espanto do público ("Nossa Senhora!"; "Vige Maria!"; etc.) ora pelo apelo a interatividade televisual sob forma de sondagem expressa de opinião, como por exemplo, no chamado "Band-pisca" do programa Brasil urgente que pede para os moradores de uma determinada área de São Paulo vista por helicóptero se pronunciar ao vivo: "Se vocês acham que o sistema de saúde no Brasil é uma porcaria, acendam e desliguem as luzes das suas casas!".

Como já foi dito essas três dimensões se auto-alimentam entre elas sem que houvesse, portanto uma total autonomia de cada uma. Além disso, são perspectivas idealtípicas que apenas expressam certas tendências nas quais não se encaixa sistematicamente a pluri-realidade dos fatos ocorridos. No entanto, como bem mostrou 
Max Weber, a idealtipificação é um processo necessário, útil e fecundo que organiza as nossas tentativas de compreensão em torno de uma realidade polimorfa e heterogênea, ao exemplo da violência mostrada .

\section{Notas}

* Doutor em Sociologia pela Universidade René Descartes (Sorbonne - Paris V), França. Professor do Programa do Pós-Graduação em Ciências Sociais da Universidade Paul Valéry - Montpellier III, França. Membro do Centre de Recherches sur l'Imaginaire e do Institut de Recherches Sociologiques \& Anthropologiques. Professor convidado pela Universidade Federal de Pernambuco (1993-95), pela Universidade Federal de Alagoas (1995-96) e pela Pontifícia Universidade Católica do Rio Grande do Sul (abril de 2004). Contato: philippe.joron@univ-montp3.fr. Universidade Federal da Paraíba - Prof. Adjunto III

1 Patrick Baudry, "Pathologisation de la violence", inVEI Enjeux, N²126, septembre 2001, p. 40 : «Ce n'est pas la violence qui doit inquiéter. Mais la fabrication systématique de la violence comme problème, comme si ce problème pouvait ou devait nous réunir.»

2 Pesquisa realizada entre fevereiro e agosto de 2004 na cidade de Recife em Pernambuco, graças ao apoio da minha universidade de origem que me concedeu uma licencia prêmio de seis meses para esse fim. Esse estudo foi fundamentado pela observação diária dos programas televisuais de jornal policial assim como por entrevistas feitas com apresentadores atuando no ramo a nível local, auxiliada pela leitura do jornal escrito Folha de Pernambuco, que dedica o caderno "Policia" e uma parte do seu site internet: www.folhape.com.br a esse assunto. Uma versão do presente texto foi apresentada na conferência de abertura do Ano Letivo do Programa de Pós-Graduação em Comunicação e Cultura Contemporâneas da Universidade Federal da Bahia, no dia 08 de junho de 2004.

3 Muniz Sodré, Sociedade, Mídia e Violência, Porto Alegre, Editora Sulina \& Edipucrs, 2002, p. 12.

4 Cf. Malu Fontes, "Os Freaks nossos de cada dia ", in A Tarde, Salvador, 06 de junho de 2004, p. 10

5 Muniz Sodré, Sociedade, Mídia e Violência, op. cit., p. 98.
Sobre essa idéia ver também Juremir Machado da Silva, Le Brésil, Pays du Présent, Paris, Desclée de Brouwer, Coll. "Sociologie du quotidien", 1999, capítulo VII : «Fiction et réalisme dans la télévision brésilienne », pp. 153-167.

6 Raymond Aron, La sociologie allemande contemporaine, Paris, Puf, coll. « quadrige», 1981 [Ed. Felix Alcan, 1935].

7 Inquisition, $\mathrm{N}^{\circ} 1,1936$.

8 Emile Durkheim, Les règles de la méthode sociologique, Paris, Puf, 1977 [1895].

9 Cf. Jules Monnerot, Les faits sociaux ne sont pas des choses, Paris, Gallimard, 1946.

10 Para uma história dessa formação intelectual, incluindo os textos fundadores e as conferências dos seus participantes, referirem-se a Denis Hollier, Le Collège de Sociologie, Paris, Gallimard, Coll. "Idées", 1979.

11 Essa sensibilidade fenomenológica esta enraizada nas diversas posturas da sociologia compreensiva em torno da vida cotidiana. Ver Michel Maffesoli, La connaissance ordinaire, Paris, Librairie des Méridiens, Coll. «Sociétés», 1985 ; Patrick Tacussel, «La sociologie interprétative. Un tournant postempirique dans les sciences humaines en France ", in Jean-Michel Berthelot, La sociologie française contemporaine, Puf, pp. 117-125.

12 Cf. Alain Touraine, Production de la société, Paris, Ed. du Seuil, 1973.

13 O lema do programa Aqui Agora (Ici et Maintenant) era: "A vida como ela é", o que lembra muito um preceito fundamental do pensamento de Montesquieu, adotado em seguida por Max Weber: mostrar a sociedade como ela é e não como deveria ser.

14 Muniz Sodré, Sociedade, Mídia e Violência, op. cit., p. 16. Ver tambem Yves Michaud, La violence, Paris, Puf, 1986.

15 Para uma análise aprofundada dos principais paradigmas teóricos em ciências da comunicação, referir-se ao estudo de Itania Maria Mota Gomes, «Efeito e Recepção: a interpretação do processo receptivo em duas tradições de investigação sobre os media», in Itania Maria Mota Gomes \& Maria Carmem Jacob de Souza, Media \& Cultura, Salvador, EDUFBA, 2003, pp. 29-53. 
16 Trata-se de um documentário de autoria inglesa que se utiliza da simulação virtual para apresentar conjecturas científicas sobre a evolução futura das espécies. Mas ao ser adaptado aos imperativos da Rede Globo, este documentário é cortado em vários trechos de três minutos semanais.

17 Por mais informações, consultar: www.ignore.com.br/antivacina.

180 processo de "elaboração" próprio a esses programas de jornalismo policial não esta sendo analisado no campo restrito deste estudo. Todavia, seria muito construtivo evidenciar o aparato criativo do ato de produção como sendo a expressão de um posicionamento autoral determinado por influências diversas. Para uma análise neste sentido das marcas autorais das telenovelas a partir da perspectiva bourdieusiana da ciência das obras, referirem-se à Maria Carmem Jacob de Souza, "Reconhecimento e consagração: premissa para análise da autoria das telenovelas", in Itania Maria Mota Gomes \& Maria Carmem Jacob de Souza, Media \& Cultura, op. cit, pp. 55-76; ver também, da mesma autora, "A construção social de sentidos e o fenômeno da recepção: em questão o papel dos realizadores", in Revista FAMECOS, N20, Porto Alegre, PUCRS, abril de 2003, pp. 46-56.

19 Cf. Alfredo Estrábica, «A produção de sentidos no jornalismo: da teoria da enunciação a enunciação jornalística", in Revista FAMECOS, No22, Porto Alegre, PUCRS, Dezembro de 2003, pp. 17-116.

$20 \mathrm{Cf}$. Georges Bataille, La part maudite, Paris, Les Éditions de Minuit, Coll. «Critique», 1967 [1949]

21 Sobre a dimensão ética, estética e sociológica do entretenimento, referir-se a Michel Maffesoli, "A comunicação sem fim (teoria pós-moderna da comunicação)", in Revista FAMECOS, No20, Porto Alegre, PUCRS, Abril de 2003, pp. 13-20.

22 Georges Bataille, L'expérience intérieure, Paris, Gallimard, Coll. «Tel», 1986 [1943], p. 113.

23 Segundo Georges Bataille que criou o termo, a heterologia define-se como a ciência dos corpos ou elementos estranhos, rejeitados a princípio pela moral e a racionalidade do projeto de homogeneidade social. Cf. Philippe Joron, « L'Hétérologie sociologique », in Annie Pibarot (org.), Ge- orges Bataille, l'héritage impossible, Montpellier, service des publications de l'Université Paul Valéry, 1999, pp. 51-71.

24 Essa prática do chicote se encontra também no Pro gama do Ratinho da mesma emissora.

25 Entrevista filmada realizada no dia 04 de maio de 2004 no estúdio da TV Tribuna. Agradecimentos à Cardinot por ter me dedicado um pouco do seu tempo, à Clélia Pinto pelo apoio técnico assim como à Maria Betânia de Oliveira Pinto por ter propiciado o encontro.

26 Cf. Michel Maffesoli, La part du diable. Précis de subversion postmoderne., Paris, Flammarion, 2002.

27 Jeremy Bentham (1748-1832), na sua Teoria das penas e recompensas, define a panótica como sendo um órgão de controle, aplicado ao sistema carceral, que possibilitaria a visualização de cada elemento do Todo. 